\title{
THE IMPORTANCE OF CREATIVITY FOR BUSINESS DEVELOPMENT IN LATVIA
}

\author{
AIJA STAŠKEVIČA \\ MARGARITA DUNSKA
}

\begin{abstract}
Today, the importance of innovation is particularly emphasised, and since creativity is the basis of innovation it is important to understand the importance of its development. This is especially essential in creative industries where creativity is the main asset of companies. It is significant to understand the factors influencing creativity in order to be able to purposefully stimulate its development. The purpose of the research is to assess the importance of creativity for the development of the company's competitiveness, determine the attitude of representatives of the Latvian creative industries towards the development of creativity, its importance as well as draw conclusions about the possibilities of its development. To meet the purpose of the research, the research methods were used as follows: document analysis, text analysis, content analysis, statistical analysis methods and questionnaire. The results of the research showed that creativity and creative industries are influenced by a wide range of factors, their development can be stimulated, and the company's creative environment can positively influence the sharing of ideas among the employees. Representatives of the Latvian creative industries understand the importance of development of the individual creativity of employees as one of the main competitive advantages in the company, but among them there is no unequivocal attitude towards whether creativity can be taught and whether it needs to be coordinated. It was also concluded that the representatives of the above industries implement innovations and focus more on product innovation.
\end{abstract}

Keywords: Latvia, creativity, creative industries, company development

JEL code: L26, L89

\section{INTRODUCTION}

In the $21^{\text {st }}$ century, the increasing export capacity of the developed EU countries is associated with creative capital. Today, changes in the global economy take place including the transition from resource-intensive industries to creative industries. Creative industries are the driving force of the economic growth, one of the fastest growing sectors in the global economy gaining increasingly important place in the national and global economy.

According to the Sustainable Development Strategy of Latvia until 2030, the source of competitiveness of these sectors is human creativity, imagination, intuition, i.e. the characteristics that depend on culture (The Saeima of 
the Republic of Latvia, 2010). Creativity development is able to increase the performance of company employees; therefore, it is important to promote the development of creativity and creative thinking that can potentially create products with greater added value. And since creativity is an intangible factor at the heart of innovation, it is subject to constant change and is not easily assessed; in practice, problems can arise in developing this capability in companies. It is important to improvise in unexpected and non-standard situations. So, it is essential to understand the creativity concept to be able to develop it.

The Latvian creative industries are the object of the research. The subject of the research is creativity management and development in the Latvian creative industries. The purpose of the research is to substantiate the importance of creativity development in business efficiency increase in the Latvian creative industries.

The main objectives are to define the concept and the importance of creativity development, list factors which influence creativity and define the possibilities of creativity measurement and assessment. The other objective is to specify the research methodology, as well as analyse the attitude and practice of creativity development in companies of the Latvian creative industries. At the end of the research, conclusions are given in order to increase the development of creativity in creative industry companies.

To meet the purpose of the research, the research methods were used as follows: document analysis, text analysis, content analysis, statistical analysis methods (grouping, comparison, statistical indicator analysis - calculation of the mean, mode, median and relative values, and correlation analysis) and a questionnaire. The data sources used in the research are: official statistical data of Latvia, international and Latvian publications in collections of scientific articles as well as information sources available on the Internet.

Limitation of investigation is that a questionnaire was distributed only among creative industry representatives in Latvia, and 136 valid questionnaires were received.

\section{RESEARCH RESULTS AND DISCUSSION}

\section{The Essence of Creativity}

Creativity and innovation are considered to be the engines of economic growth. Creativity is one of the most important factors contributing to a more complete and satisfying life, and is one of the main keys to survival in modern organisations (Sik, 2016). Various creativity tools and techniques the use of which is the organisation's competitive advantage have been widely practiced in larger companies over the last decades (Bertoncelli, Mayer, Lynass, 2016). Regardless of the field of activity, if a company continues operating without changes, it may cause long-term risks in comparison to those trying new ways 
to create better products, approaches, processes or services and continuously improve. "If a company does not make changes, others will do it faster and will be more competitive as a result of creative and innovative approach" (Revelle, 2014).

Creativity is extensively explored, and there is still a debate among scholars as to whether creativity is a feature affecting different fields or its consequences are specific in a particular field, for instance, art, music, and mathematics (Schlee and Harich, 2014). At present, there are more than 100 creativity definitions (Sik, 2016).

T. Amabile, M. Mumford, and S. Gustafson describe creativity as "the emergence of a new and potentially useful idea to achieve the desired goals" (Mumford and Gustafson, 1988, Bratnicka, 2015). Professor M. Boden stated that creativity is "the ability to come up with ideas and artefacts that are new, striking, and valuable" (Boden, 2011). G. Cox defines it in Cox Review of Creativity in Business as "generating a new idea or way of looking at existing problems - or the possibility to see new opportunities using new technologies or changes in the market" (Cox, 2005). According to the findings of the United Nations Conference on Trade and Development (UNCTAD), the term "creativity" relates to originality, imagination, innovation, inspiration, imagination and inventiveness. It is an essential feature of people who are imaginative, resourceful and capable of finding great knowledge-based ideas, and these ideas are the essence of intellectual capital" (UNCTAD, 2008). The Sustainable Development Strategy of Latvia until 2030 states that "creativity is an inherited and developed personality trait/ability to create original and new-value images". Creative activity helps discover new opportunities and forms for better cohabitation and activity models, adapting to new conditions and transforming existence by means of creative imagination and initiative" (The Saeima of the Republic of Latvia, 2010).

In general, most of the respective literature defines creativity as a process that brings something new and useful (Chang et al., 2016).

In practice, there may be a lack of clarity between creativity and innovation; that is why, to reduce this uncertainty, differences between concepts will be defined. Creativity is the ability to find original ideas, i.e. see one more or several different ways of doing something. Thus, creativity is the ability to invent new things or create new combinations of things, whereas innovation is the ability to actually do new things. Innovations create new things or solve a problem by putting a new combination together (Revelle, 2014). So, creativity is thinking, and innovation is implementation.

Over time, two different ways of defining creativity have been developed (Figure 1).

D. McKinnon stated that creativity is not only the generation of new ideas; it should also be of social significance (MacKinnon, 1965). From the system view, creativity is the process resulting from interaction in a particular system, and creativity matters only in relation to the system which assesses it. This social perspective emphasises that creativity is not a separate process, but requires 
a welcoming audience to implement creative ideas; so, without any kind of public recognition a new idea cannot be considered as creativity. Based on this point of view, creativity stems from three elements in relation to the system in which interact:

(1) a culture with symbolic rules;

(2) a person bringing creativity in the symbolic area;

(3) experts who recognise and confirm innovation (Sik, 2016).

On the other hand, creativity is defined, from a personal perspective, as "the psychological involvement of a person in creative activity", and emphasis is placed on the person's achievements regardless of their usefulness to society. Professor R. Sternberg emphasised novelty and high quality, and did not emphasise social usefulness, which could be dealt with differently in different fields. Even though in the standard definition of creativity, i.e. creativity requires originality and efficiency, a company may have a different point of view on what is efficiency (Sternberg, 1999). Thus, from a personal perspective, social usefulness is regarded as an unnecessary limitation in creativity.

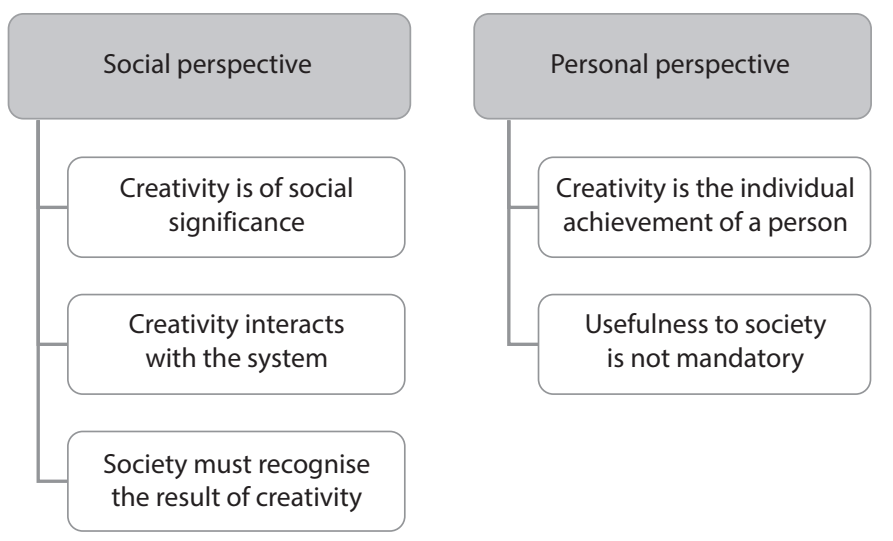

Source: authors' construction based on Sik, 2016

Fig. 1. Prospects for Defining Creativity

In the various fields of human activity, the characteristics of creativity can be formulated differently. For instance, artistic creativity involves imagination and the ability to create original ideas, or speech abilities as to how to interpret the world, express text, sound and image. Economic creativity is a "dynamic process that leads to innovation in technology, business practice, marketing, and is closely linked to gaining competitive advantage in the economy" (Sik, 2016). Organisational creativity is defined as the ability of an organisation to create an idea that is simultaneously new and useful. Individual creativity plays an important role in every organisation's creativity. The existence of a creative team depends on creative individuals, and the existence of a creative organisation 
depends on creative teams. The organisation's performance is maximised when the type and degree of individual (team) investment is differentiated in a collective outcome. Collective creative practice can facilitate the effectiveness of an organisation only if each member of the team makes a distinct contribution influencing his or her particular creativity but coordinates what he or she does with the other group members in organisations. With increasing complexity of the requirements and uncertainties, the organisation's (team's) contribution and effectiveness must be relatively different from team (individual) contribution and efficiency (Bratnicka, 2015).

Due to the essential role played by creativity in the development of a company, both the researchers and practitioners are trying to find ways to promote and develop creativity, and through this process to also facilitate innovation. According to the latest literature, creativity can indeed be stimulated, maintained and can be learned. There are different methods of creativity stimulation used by the companies. The creativity stimulation methods most commonly used in Europe are brainstorming and multifunctional teams.

Brainstorming is one of the most popular and most recognisable methods in all business practices. It is a creative task - generating ideas within a group. This technique is often used in the innovation development process, especially at an early stage.

Likewise, innovative companies rely extensively on the interfunctional (or multi-functional) teams when it comes to the development of new products since they accelerate the product development process (Botrić and Božić, 2015). $\mathrm{R}$. Cooper concluded that identified interpersonal teams are one of the most important success factors in the innovation projects (Cooper, 1999). Interfunctional teams contribute to the success of innovative projects, but they are not easy to implement. This is mainly due to the different approaches, goals of the group members, as well as potential conflicts that may arise between business functions. Team responsibility and organisational culture that supports the team work could contribute to the successful multi-functional team implementation. However, this requires a rather developed organisational culture.

Work specialisation is often associated with boredom and monotonous work with a limited number of operations done each day. In these situations, it is good to engage the work rotation schemes to provide a better understanding of the activities of other departments, which could ultimately stimulate the creativity of employees. However, work rotation has disadvantages if employees find some work places to be less attractive or valuable. In addition, agreeing on the respective salary rates to do different jobs may be topical.

In turn, financial remuneration can potentially ensure the meeting of the organisation's diverse goals, including innovation-related ones. However, it does not always mean that this would lead to the results desired, and even scientific literature captures the negative effects of remuneration on creativity and innovation. Therefore, based on the scientific evidence, financial remuneration schemes should 
not include the goal of achieving the specific results, but rather the desired action which is particularly important in innovation and creativity. Benefits should include competencies, attempts and achievements in creativity (Botrić and Božić, 2015). F. Ederer and G. Manso also concluded that incentive payments allowing for early failure stimulate innovation (Ederer and Manso, 2013).

Non-financial incentives such as public recognition, more interesting position, decision-making autonomy, job security and an attractive location are used to reward employees. G. Oldham and A. Cummings proved that the encouragement of the superior is of great importance in the facilitation of the employee's creativity (Oldham and Cummings, 1996).

Many problem-solving methods are taught at large universities and companies with the purpose to promote ideas and enhance creativity (Bertoncelli, Mayer and Lynass, 2016). A person can be creative, talented and ingenious from birth but, as it has already been mentioned, creativity can be developed. M. Basadur, M. Wakabayashiand G. Graen have shown that training programmes have a positive effect on the creativity of employees (Basadur, Wakabayashi and Graen, 1990).

The above methods are among the best tools for promoting creativity and, as a result, innovation, but the implementation of these methods requires skills and competence. Given the complexity of creativity and innovation processes, positive results cannot be guaranteed.

So nowadays, creativity is an important person's quality; and even though there still is a dispute as to whether creativity must be recognised by society, it needs to bring something new and useful in business. The more different the contribution the members of the organisation's teams make, the greater results they can achieve. Therefore, individual creativity plays an important role in each organisation's creativity, but its action must be coordinated. Creativity is developed and trained in companies since it is the basis for innovation, which today is one of the most important drivers of the economy and is the core asset and competitive advantage of creative industries.

The term "creative industries" was first documented in Australia in 1994, but it became more widespread in 1997 when the United Kingdom government Department of Culture, Media and Sport (DCMS) formed creative sectoral working group (Marinova and Borza, 2014). In 1998, DCMS published the creative industries mapping document including a definition and thirteen sub-sectors which were no longer referred to as cultural industries, as before (Maryunani and Mirzanti, 2015). DCMS used the term "creative industries" to classify industries originating from individual creativity, skills and talent, and having potential for wealth creation and job creation through the generation and use of intellectual property (Lee and Drever, 2013). According to the DCMS's creative industry mapping document, creative industries are: advertising, architecture, art and antiquities market, crafts, design, fashion, cinema, video and photography, interactive entertainment software (computer games), music, performing arts, publishing, software and computer services, television and radio (Sung, 2015). 
The Ministry of Culture of the Republic of Latvia also includes similar industries in the cultural and creative industries: architecture, design, cinema, performing arts, visual arts, music, publishing, television, radio and interactive media, advertising, computer games and interactive software, cultural heritage, cultural education, recreation, entertainment and other cultural activities (Ministry of Culture, RL 2018).

Creative industries stand out from the rest because their products include symbolic and aesthetic values. It has important consequences for pricing and market entry. For consumers, the value of such products exceeds their value in use and is not directly related to the cost of production.

\section{Factors Influencing Creativity and Creative Industries}

Creativity is influenced by many factors. The research will summarise the main factors influencing creativity that are most frequently observed in the scientific literature. According to E. Martinaityte and R. Kregždaite, the research on The Factors of Creative Industries Development in Nowadays Stage, the creative industry sector is highly influenced by the costs of culture and recreation and the level (index) of the people's creativity. The creative industry sector is moderately influenced by: government expenditure for culture, number of patents per million inhabitants, employment rate in research and development, number of students applying for art and humanities, and the level of tolerance. The level of employment in creative industries, the share of their exports, government expenditure for research and development have a low degree of influence (Martinaitytè and Kregždaitè, 2015).

R. Sternberg pointed out that the essence of creativity is rather complicated since it requires a lot of such resources as intellectual skills, knowledge, motivation, personality, style of thinking and environment. Exactly the environment is one of the essential components of creativity, but it is important to use all of the above resources rather than to be their owners (Sternberg, 2006). It also implies that creativity is not only an essential feature - it can be developed and facilitated.

The American theorist R. Florida suggested that the city's creative community is a key element in the development of creative industries. He put forward the theory of 3 T's suggesting that creative talent, creative technology, and the city's cultural tolerance are essential for the development of the city's creative industries (Florida, 2002).

J. Zhou, C. Shalley et al. argued that creativity of employees is a function of personal qualities related to the context of work and interacts with the personal and contextual parameters (Zhou and Shalley, 2009; Oldham and Cummings, 1996). Thus, creativity depends on the situation. Namely, a person can be creative without a creative personality, and in terms of creativity and entrepreneurship it can derive from situations, contexts and other factors rather than from individual factors related to personality. Like W. Johnson et al. wrote, "even very heritable features can be strictly manipulated by the environment" (Johnson et al., 2009). 
T. Amabile used a model of creativity and innovation components that includes organisational motivation to innovate. Dimensions included the availability of resources, time for ideas, learning, compliance with freedoms and challenges, and other factors. Management plays an important role in promoting a creative environment through the provision and management of a work environment in which creative individuals can operate. In the work environment and climate geared towards creative thinking, there is a much greater potential for production of creative products than in a company with a slow, bureaucratic structure (Amabile, 1988).

M. Jensen and S. Beckmann measured the organisational structure and climate and found that innovation and creativity were strategic disciplines depending on social relations. The key innovations and dimensions of creativity driving forces are support for ideas, dynamism, debate, risk taking and ideas (Jensen and Beckmann, 2009).

Psychologist H. Eysenck identified a set of variables that have an impact on creativity. These are cognitive variables (intelligence, knowledge, technical skills and special talent), environmental variables (political, religious, cultural, socioeconomic and educational factors) and personality variables (internal motivation, trust, discrepancy and creative thinking skills) (Eysenck, 1996).

The results of S. Shane's and N. Nicolaou's study Creative Personality, Opportunity Recognition and the Tendency to Start Businesses confirmed that people with a creative personality have a significantly greater tendency to recognise business opportunities and start a business than the others. It was found that genetics have a significant effect on creativity. Genetic factors account for $66 \%$ of the correlation between the creative personality and opportunity recognition, and $82 \%$ - of the correlation between the creative personality and the tendency to start a business. Because of the high correlation between creativity and opportunity recognition, employers could consider using a creative personality test to identify employees to be engaged in the jobs where opportunity recognition is important (Shane and Nicolaou, 2015). Further evidence suggests that creativity and entrepreneurship are interconnected. For instance, D. Hull, J. Bosley and G. Udell surveyed university graduates and found that in terms of creativity the business owners were valued higher than non-owners. But it should be borne in mind that creative personality can be developed in life, and the development of a creative personality increases the likelihood that people will become entrepreneurs which could be the result of both genetic and environmental influences (Hull, Bosley and Udell, 1980).

G. Hearn, S. Cunningham and D. Ordonez suggested that a strong intellectual property protection mechanism, creation of vibrant creative talent groups, a broad platform for information exchange and a perfect risk investment system are important factors for the development of creative industries (Hearn, Cunningham and Ordonez, 2004). A creative product is a very special product that can be easily copied by other people. Intellectual property rights are the granting of legal and exclusive rights to the original creator according to which he or she owns and 
controls the intellectual product (Dong, $\mathrm{Zhu}$ and $\mathrm{Hu}, 2015$ ). Intellectual property protection reduces the possibilities for copying the creative result and is one of the means to protect the repayment of the invested funds; it can stimulate the creation of innovations which is a positive driver for industrial development. Here it should be mentioned that according to the research The Functioning of Latvian Creative Industries and Preconditions for Targeted Development of the Industry conducted by Baltijas Konsultācijas LLC and Konsorts LLC, Latvian small and medium-sized enterprises rarely use the opportunities to strengthen their intellectual property. This is due to the lack of resources, interest and knowledge, as well as the complicated procedures (Baltijas Konsultācijas LLC and Konsorts LLC, 2013). This could hinder the development of creative industries.

Another factor influencing creativity that is specifically topical nowadays is the impact of information and communication technology (ICT) the use of which is one of the main sources of competitive advantage for businesses. Due to ICT, there are important changes in creative industries both in terms of demand and supply. Even though the same trends can be observed in other areas of digital content, changes in the business models of creative industries are specific because they relate to efficiency in combination with different resources involved in the process of creation, for instance, skills, talent and technology. The development of new technologies and online market has contributed to the new service opportunities, market expansion and globalisation, new offers and new relationships with customers (social media, recommendations and comments). The creators of creative products can collaborate in geographically dispersed groups, as well as there is interaction between the creators, content providers and potential users. Content development is the result of joint efforts by various operators, professionals and amateurs which enables them to share and distribute the costs of initial design, publishing and distribution between the parties. Moreover, greater communication between consumers and creators makes the content more tailored to user needs, which reduces uncertainty and promotes development (Lyubareva, Benghozi and Fidele, 2014). But, on the other hand, ICT enables others to copy and transfer the creative content at a very low cost. It has a significant impact on publication, promotion and dissemination. When the marginal cost becomes low and almost insignificant, it provides significant advantages to the copiers. Even if such changes offer great opportunities from the point of view of the consumer, they pose a threat to creative industries. Therefore, researchers E. Moyon and K. Lecocq concluded that the development of creative industries requires innovation in two key areas. Firstly, legal bodies must develop new structures to maintain intellectual property rights. Secondly, organisations working in creative industries need to rethink their business models in order to remain profitable and competitive in a changing environment (Moyon and Lecocq, 2014). 
The national culture also influences the economic creativity. It has been proved that an individual from a stringent culture engages and succeeds in foreign creative tasks that are culturally far away less than a person from an open culture. On the contrary, for the pursuit of local creative tasks, cultural tensions increase participation and the possibility of success. These findings demonstrate the impact of cultural standards on creativity on a global scale. It is more likely that people from a stringent culture will engage and succeed in culturally similar foreign creative tasks. For people from a stringent culture, when foreign standards are very similar, there is an understanding of their local rules giving them an advantage in creativity. But the tighter the specific culture is, the harder it is to do creative work successfully because of the difficulty of meeting the cultural standards. This finding suggests that stringent cultures are difficult to satisfy by the foreign inventors. Also, innovators from a tight culture appear less frequently than from the loose cultures and are less likely to use the ideas of foreign culture. And, in general, cultural tension is a threat to creativity (Chua, Roth and Lemoine, 2015). In addition, the evidence that a stringent culture can hinder an individual's ability to generate innovative ideas is in line with R. Florida's assertion that tolerant cultures are an important predictor of urban creativity.

Creativity studies have so far highlighted the importance of divergent thinking, whereas scientists also argue that convergent thinking plays a critical role. J. Goncalo and M. Duguid found that creative success is facilitated by the compliance rules of a team whose members are not particularly creative (Goncalo and Duguid, 2012). Coordinated thinking helps evaluate the practicality of an innovative idea and implement it. Divergent thinking has a great power in the generation of innovative ideas, whereas coordinated thinking needs to find out whether these ideas could be useful in the context of the given problems.

The main factors influencing the creative industries are summarised in the Table 1.

Table 1

Summary of the Main Factors Influencing the Creative Industries

\begin{tabular}{|l|l|}
\hline \multicolumn{1}{|c|}{ Author(s) } & \multicolumn{1}{c|}{ Factors } \\
\hline $\begin{array}{l}\text { E. Martinaityté, } \\
\text { R. Kregždaite (2015) }\end{array}$ & $\begin{array}{l}\text { People's level of creativity, expenditure for culture and recreation, } \\
\text { government expenditure for culture, number of patents per million } \\
\text { inhabitants, employment rate in research and development, number } \\
\text { of students applying for arts and humanities, tolerance level }\end{array}$ \\
\hline R. Sternberg (2006) & $\begin{array}{l}\text { Intellectual skills, knowledge, motivation, personality, thinking style } \\
\text { (use of these factors and training), environment }\end{array}$ \\
\hline R. Florida (2002) & Creative talent, creative technology, city's cultural tolerance \\
\hline $\begin{array}{l}\text { J. Zhou, C. Shalley } \\
\text { (2009); G. Oldham, } \\
\text { A. Cummings (1996) }\end{array}$ & Personal qualities, contextual parameters or situation \\
\hline
\end{tabular}




\begin{tabular}{|c|c|}
\hline Author(s) & Factors \\
\hline T. Amabile (1988) & $\begin{array}{l}\text { Organisational motivation for innovation (including: availability of } \\
\text { resources, time for ideas, training, compliance with freedoms and } \\
\text { challenges, management support for the building of a creative work } \\
\text { climate) }\end{array}$ \\
\hline $\begin{array}{l}\text { M. Jensen, S. Beckmann } \\
(2009)\end{array}$ & $\begin{array}{l}\text { Social relationships (support for ideas, dynamism, debates, risk } \\
\text { taking and idea) }\end{array}$ \\
\hline H. Eysenck (1996) & $\begin{array}{l}\text { Cognitive variables (intelligence, knowledge, technical skills and } \\
\text { special talent), environmental variables (political, religious, cultural, } \\
\text { socioeconomic and educational factors) and personality variables } \\
\text { (internal motivation, trust, discrepancy and creative thinking skills) }\end{array}$ \\
\hline $\begin{array}{l}\text { S. Shane, N. Nicolaou } \\
(2015)\end{array}$ & Genetic factors or creative personality \\
\hline $\begin{array}{l}\text { G. Hearn, } \\
\text { S. Cunningham, } \\
\text { D. Ordonez (2004) }\end{array}$ & $\begin{array}{l}\text { Intellectual property protection mechanism, creation of energetic } \\
\text { creative talent groups, wide platform for information exchange }\end{array}$ \\
\hline $\begin{array}{l}\text { I. Lyubareva, } \\
\text { P. Benghozi, T. Fidele } \\
(2014)\end{array}$ & Information and communication technology \\
\hline $\begin{array}{l}\text { R. Chua, J. Roth, } \\
\text { J. Lemoine (2015) }\end{array}$ & National culture, its openness, stringency \\
\hline $\begin{array}{l}\text { J. Goncalo, M. Duguid } \\
\text { (2012) }\end{array}$ & Divergent and convergent thinking \\
\hline
\end{tabular}

Source: authors' construction based on literature review

In general, it may be concluded that creativity is influenced by the environment, situation and genetics, and it can be developed during a lifetime.

\section{Research Methodology}

To determine the attitude of creative industry representatives towards creativity and its significance, as well as to assess company practices in the development of creativity in the Latvian creative industries, an empirical study was conducted. The individual questionnaire was disseminated electronically via the homepage visidati.lv. The link to it was emailed to 1093 representatives of creative industry companies. It was available both in Latvian and Russian. As a result, out of all emailed questionnaires $12.4 \%$ or 136 filled out questionnaires were received. After processing, the total results of the survey were obtained with the proportion of the responses of each statement and the different response rates: mean, median, mode, Pearson correlation coefficient.

In the questionnaire, the respondents had to choose the right option for their company, i.e. the type of activity, duration, turnover and turnover growth over the last three years. The respondents had to assess the extent to which 
the respondents agreed with each of the statements about creativity and the factors influencing a creative company. These questions were asked to identify the respondents' attitude towards creativity, the creative environment and the creativity facilitation practices used. They made it possible to compare the company representatives' points of view and practices in companies. Questions related to the assessment of innovation and creativity in a company were asked in order to determine whether companies stimulate creativity and, as a result, the source of innovation as a competitive advantage and the possibility of increased efficiency.

The representatives from different creative industries participated in the survey (Table 2). The majority or $29.4 \%$ represented the design, photographic and translation services sectors. $15.4 \%$ of the companies were related to the activities of art and cultural institutions, $13.2 \%$ - to crafts, $12.5 \%$ - to architecture.

Table 2

Lines of Business of Respondent Companies

\begin{tabular}{|c|l|c|}
\hline No. & \multicolumn{1}{|c|}{ Questionnaire participant's industry } & $\begin{array}{c}\text { Percentage of } \\
\text { analysable totality }\end{array}$ \\
\hline 1 & Design, photographic services, translation and interpreting sector & $29.4 \%$ \\
\hline 2 & Art and culture institutions & $15.4 \%$ \\
\hline 3 & Artisanship & $13.2 \%$ \\
\hline 4 & Architecture & $12.5 \%$ \\
\hline 5 & Film, television, music, radio & $8.1 \%$ \\
\hline 6 & Computer programming and computer services sector & $7.4 \%$ \\
\hline 7 & Other creative industries & $13.9 \%$ \\
\hline
\end{tabular}

Source: authors' construction based on the research results

At the time of completing the questionnaire, the duration of activity of the majority of respondents ( $48.5 \%$ or 66 representatives) was more than seven years. The duration of activity of 32 respondents was 4-7 years, of 31 respondents 1-3 years, and of 7 respondents - up to 1 year. The turnover of the investigated companies was very diverse. $14.4 \%$ of the surveyed companies were very small with the turnover up to EUR 5 thousand per year. In these companies, the owner or merchant is most often also the sole employee. The turnover of $16.7 \%$ companies was over EUR 500 thousand per year.

In the following questions the creative industry representatives were asked to assess the extent to which the respondents agreed with each of the statements about their attitude to creativity and creativity stimulating practices in their companies at the scale from 1 to 5 (where 1 - completely disagree and 5 -fully agree). The detailed results of each question are summarised in Table 3. 
Table 3

Questionnaire Statement Results

\begin{tabular}{|c|c|c|c|c|c|c|c|c|c|c|}
\hline No. & Statement & Mean & Median & Mode & 1 & 2 & 3 & 4 & 5 & $\begin{array}{l}\text { Not } \\
\text { sure }\end{array}$ \\
\hline 1 & $\begin{array}{l}\text { It is important to develop } \\
\text { the individual creativity of } \\
\text { the company's employees }\end{array}$ & 4.45 & 5 & 5 & 1 & 2 & 18 & 27 & 85 & 3 \\
\hline 2 & $\begin{array}{l}\text { It is impossible to teach and } \\
\text { develop creativity }\end{array}$ & 3.11 & 3 & 3 & 18 & 26 & 37 & 22 & 27 & 6 \\
\hline 3 & $\begin{array}{l}\text { It is important to coordinate } \\
\text { and control the employee's } \\
\text { creative process }\end{array}$ & 3.52 & 4 & 4 & 9 & 18 & 28 & 38 & 31 & 12 \\
\hline 4 & $\begin{array}{l}\text { Latvia has an open and } \\
\text { tolerant culture }\end{array}$ & 3.08 & 3 & 3 & 8 & 32 & 47 & 26 & 16 & 7 \\
\hline 5 & $\begin{array}{l}\text { The offer of Latvian } \\
\text { educational programmes } \\
\text { in creative/your field is } \\
\text { in line with the market } \\
\text { requirements }\end{array}$ & 2.57 & 2 & 2 & 31 & 35 & 32 & 23 & 9 & 6 \\
\hline 6 & $\begin{array}{l}\text { The country has extensive } \\
\text { information on your } \\
\text { industry issues, including } \\
\text { support options }\end{array}$ & 2.55 & 3 & 3 & 30 & 35 & 39 & 20 & 8 & 4 \\
\hline 7 & $\begin{array}{l}\text { Something new was } \\
\text { introduced into your } \\
\text { product/service in the last } \\
12 \text { months } \\
\end{array}$ & 4.14 & 5 & 5 & 10 & 11 & 4 & 32 & 75 & 4 \\
\hline 8 & $\begin{array}{l}\text { New work practices/new } \\
\text { equipment were introduced } \\
\text { in your company in the last } \\
12 \text { months }\end{array}$ & 3.47 & 4 & 5 & 27 & 14 & 13 & 25 & 52 & 5 \\
\hline 9 & $\begin{array}{l}\text { When selecting } \\
\text { an employee, his or her } \\
\text { ability to be creative is also } \\
\text { assessed }\end{array}$ & 3.96 & 4 & 5 & 6 & 7 & 24 & 34 & 51 & 14 \\
\hline 10 & $\begin{array}{l}\text { A work environment } \\
\text { stimulating creativity and } \\
\text { new ideas has been created } \\
\text { in the company }\end{array}$ & 3.57 & 4 & 5 & 10 & 14 & 33 & 33 & 37 & 9 \\
\hline 11 & $\begin{array}{l}\text { A system of } \\
\text { recommendations has been } \\
\text { developed in the company }\end{array}$ & 2.91 & 3 & 4 & 27 & 20 & 27 & 29 & 17 & 16 \\
\hline 12 & $\begin{array}{l}\text { Employees openly share } \\
\text { their creative ideas with } \\
\text { others }\end{array}$ & 3.87 & 4 & 5 & 4 & 15 & 22 & 34 & 48 & 13 \\
\hline
\end{tabular}

Source: authors' construction based on the research results 
In general, it can be concluded that the absolute majority, i.e. $82.4 \%$ of the respondents, totally or rather agreed that it is really important to develop the individual creativity of the company's employees. The median in this question is 5. Thus, the respondents are aware that creativity is one of the main sources of advantage in their work. Despite the fact that a recent research has shown that creativity can be developed and trained, there is no common opinion among the respondents as to whether creativity can be taught. The mean value is 3.11 and the median -3 . The opinions are completely divided and contrary $-32.4 \%$ consider or rather agree that creativity can be taught, $36 \%$ - agree or rather agree that creativity cannot be taught, whereas $27.2 \%$ gave an average assessment 3 to this question. Similarly, there is no unequivocal attitude towards the statement "It is important to coordinate and control the employees' creative process." Nevertheless, the median and mode is 4 , and the majority or $50.7 \%$ completely or rather agreed with this statement, 19.9\% - rather disagreed with it, and $29.4 \%$ rated it with 3 or it was hard for them to say.

Based on the researchers' findings, openness and tolerance of the national culture have a significant impact on the people's creativity. The respondents' opinions were totally divided in relation to the openness of Latvia's culture and the level of tolerance. This is also confirmed by the mode and median score of 3 , and an average of 3.08. 30.9\% fully or rather agreed that there is an open and tolerant culture in Latvia, $29.4 \%$ of the respondents did not agree, and $34.6 \%$ gave the assessment $3.48 .5 \%$ of the respondents fully or rather agreed that the Latvian educational programme offer in their sectors does not meet the market requirements, only $23.5 \%$ of the respondents rather or fully agreed that the educational programme offer still meets said requirements. This poses a threat to the fact that students are not competitive after training, and their potential is not developed to the maximum since training and development are the foundation of new idea creation. Similar results are in the statement on the availability of information on creative industry issues, including support options. $47.8 \%$ of the respondents believed that this information is fully or rather not widely available and only $5.9 \%$ of the respondents fully agreed with the statement. It is positive that in the innovation survey, the majority (55.1\%) of the respondents acknowledged that something new was introduced in their product or service over the last 12 months, and $23.5 \%$ of the respondents rather agreed with this statement. This means that the majority of creative companies implement product innovations. Slightly less, i.e. 56.6\% of the respondents, fully or rather agreed that new work practices (or equipment) were introduced. So, the process innovation is introduced but less frequently than the product innovation. One fifth (19.9\%) did not introduce any new work practice in the last 12 months. It should be pointed out that the majority indicated that when selecting a staff member, his or her ability to be creative was also assessed. $62.5 \%$ fully or rather agreed with this statement. It is positive because, due to the high correlation between the creative personality and opportunity recognition, identification of the employee's creativity allows offering the right job to him or her, assigning employees to the work places where 
business opportunity recognition is important, and developing the employee's individual development plan that promotes individual creativity development.

The company's environment facilitating creativity was assessed rather differently. $27.2 \%$ of the respondents fully agreed to the statement that their company was ensuring a work environment stimulating creativity, $24.3 \%$ of the respondents gave the assessment 4 , and the same percentage of the respondents gave the assessment $3 ; 10.3 \%$ the respondents rather disagreed with this statement, and $7.4 \%$ - completely disagreed.

In order to understand the relationship between the questionnaire statement results and the duration of business, its turnover growth and size, the Pearson correlation coefficient between these indices was calculated. In general, research interrelations are not close, which means that there is no close correlation between the responses to the statements and the size and turnover of the companies. However, it was found that there is a weak negative interrelation between the company's operating life and introduction of product innovations over the last 12 months, i.e., the larger the company and its duration, the less it was noted that it had introduced product innovations in the last year. The correlation coefficient $R=-0.201$ where the correlation coefficient is statistically significant with the probability value $p=0.981$ or with the significance level $\alpha=0.019$. Similar results are also found in the correlation between the company's turnover and the introduction of product innovations. These results confirm the tendency for smaller companies to innovate. There is a positive weak correlation between the turnover increase and the introduction of product innovations. The correlation coefficient $R=0.289$ where the correlation coefficient is statistically significant with the probability value $p=0,999$ or with the significance level $\alpha=0.001$. And the greater correlation is the interrelation of process innovations with the increase in turnover. The correlation coefficient $R=0.317$ where the correlation coefficient is statistically significant with the probability value $p=1$ or with the significance level $\alpha=0$. Consequently, the introduction of new work practices has a greater influence on the turnover growth. It should be pointed out that there is a weak and negative correlation between the development of the system of recommendations and the company's duration. This means that there is a tendency for new companies to develop the recommendation systems. A positive relationship is also between turnover growth and open sharing of ideas. The correlation coefficient $R=0.238$ where the correlation coefficient is statistically significant with the probability value $\mathrm{p}=0.995$ or with the significance level $\alpha=0.005$.

An averagely strong positive correlation exists between the introduction of product and process innovations. The correlation coefficient $R=0.562$, where the correlation coefficient is statistically significant with the probability value $p=1$ or with the significance level $\alpha=0$. Companies introducing a new product are more likely to introduce innovations in the process, and vice versa. There is also an averagely strong positive correlation between the provision of a creative working environment and the sharing of employees with creative ideas. The correlation 
coefficient $R=0.460$ where the correlation coefficient is statistically significant with the probability value $p=1$ or with the significance level $\alpha=0.000$.

Thus, the representatives of the Latvian creative industries are aware of the importance of implementation of creativity and innovation, and there are opportunities to improve their activities by purposefully developing the level of the employees' creativity and process innovation taking into account the factors influencing creativity. This can lead to an increase in the companies' turnover.

\section{CONCLUSIONS}

1. Creativity is a process that brings something new and useful. Creative industries stand out from the rest because their products include symbolic and aesthetic values. For consumers, the value of such products exceeds their value in use and is not directly related to the cost of production.

2. Creativity is influenced by the environment, situation and genetics, and it can be developed throughout life. Therefore, managers should ensure the environment and training programme facilitating creativity in the company.

3. The representatives of the Latvian creative industries understand the importance of developing of the employees' individual creativity as one of the main competitive advantages in a company.

4. Among the Latvian creative industries there is no unequivocal attitude as to whether creativity can be taught and whether it needs to be coordinated. The creative industry representatives should be aware that creativity may be developed using the creativity stimulation techniques, but it needs to be controlled to achieve more effective results.

5. Among the Latvian creative industries there is no unequivocal attitude towards the level of openness of the country's culture, which has a significant influence on the development of creativity and creative industries; the companies' creativity environment was also assessed rather differently. Entrepreneurs should especially work to build a creative work environment since it is one of the most important factors influencing new ideas, and the potential to create creative production is greater in the climate facilitating creativity.

6. Almost half of the respondents believe that the offer of Latvian educational programmes in their sectors does not meet the requirements of the market. A great deal of attention should be paid to education in creative industries since it is the basis for the facilitation of creativity.

7. It is positive that the Latvian creative companies introduced both product and process innovations over the last 12 months. But process innovation is introduced less often than product innovation. This is due to the fact that entrepreneurs focus more on the finished product. The creative industry entrepreneurs should also focus on the improvement of the process since the introduction of new work practices has a greater influence on turnover 
growth than the introduction of new products. Companies introducing a new product are more likely to introduce innovations in the process, and vice versa.

8. Smaller companies are more likely to innovate. The company's open culture in which the exchange of information is facilitated is related to turnover growth.

9. The company's creative environment has a positive impact on the sharing of ideas among employees which, in the long run, gives the possibility to develop innovations.

\section{REFERENCES}

Amabile, T. (1988). A model of creativity and innovation in organizations. Research in Organizational Behavior, 10, 123-167.

Baltijas Konsultācijas LLC and Konsorts LLC (2013). Latvijas radošo industriju darbība un priekšnoteikumi nozares mērḳtiecìgai attīstîbai. Rìga, $181 \mathrm{p}$.

Basadur, M., Wakabayashi, M., Graen, G. B. (1990). Individual Problem-Solving Styles and Attitudes Toward Divergent Thinking Before and After Training. Creativity Research Journal, 3, 22-32.

Bertoncelli, T., Mayer, O., Lynass, M. (2016). Creativity, Learning Techniques and TRIZ. Procedia CIRP, 39, 191-196.

Boden, M. A. (2011). Creativity and Art: Three Roads to Surprise. Oxford: Oxford University Press. 260 p.

Botrić, V., Božić, L. (2015). Fostering Innovation through Creativity Stimulation Methods in Croatia. International Journal of Business \& Economic Sciences Applied Research, 8(1), 7-23.

Bratnicka, K. (2015). Creativity and effectiveness in organizations. A new approach to an old question. Management, 19(1), 33-45.

Chang, Y. S., Chien, Y. H., Yu, K. C., Chu, Y. C., Chen, M. (2016). Effect of TRIZ on the creativity of engineering students. Thinking Skills and Creativity, 19, 112-122.

Chua, R. Y. J., Roth, Y., Lemoine, J. F. (2015). The Impact of Culture on Creativity: How Cultural Tightness and Cultural Distance Affect Global Innovation Crowdsourcing Work. Administrative Science Quarterly, 60(2), 189-227.

Cooper, R. G. (1999). The Invisible Success Factors in Product Innovation. Journal of Product Innovation Management, 16(2), 115-133.

Cox, G. (2005). Cox Review of Creativity in Business: Building on the UK's Strengths. London: Design Council, $46 \mathrm{p}$.

Dong, X., Zhu, H., Hu, C. Q. (2015). Protection of Intellectual Property Rights and Industrial Agglomeration: Evidence From the Creative Industries in China. Chinese Economy, 48(1), 22-40.

Ederer, F., Manso, G. (2013). Is Pay-for-Performance Detrimental to Innovation? Management Science, 59(7), 1496-1513.

Eysenck, H. J. (1996). The measurement of creativity. In M. A. Boden (Ed.), Dimensions of creativity. MIT Press, pp. 199-242.

Florida, R. (2002). The Rise of the Creative Class: And How It's Transforming Work, Leisure, Community, and Everyday life. Basic Books. 434 p.

Goncalo, J. A., Duguid, M. M. (2012). Follow the crowd in a new direction: When conformity pressure facilitates group creativity (and when it does not). Organizational Behavior and Human Decision Processes, 118, 14-23. 
Hearn, G. N., Cunningham, S. D., Ordonez, D. (2004). Commercialisation of knowledge in universities: The case of the creative industries. Prometheus, 22, 189-200.

Hull, D., Bosley, J., Udell, G. (1980). Renewing the hunt for the Heffalump: identifying potential entrepreneurs by personality characteristics. Journal of Small Business Management, 18(1), 11-18.

Jensen, M. B., Beckmann, S. C. (2009). Determinants of innovation and creativity in corporate branding: findings from Denmark. Journal of Brand Management, 16(7), 468-479.

Johnson, W., Turkheimer, E., Gottesman, I. I., Bouchard, T. J. Jr. (2009). Beyond Heritability: Twin Studies in Behavioral Research. Current Directions in Psychological Science, 18(4), 217-220.

Lee, N., Drever, E. (2013). The Creative Industries, Creative Occupations and Innovation in London. European Planning Studies, 21(12), 1977-1997.

Lyubareva, I., Benghozi, P. J., Fidele, T. (2014). Online Business Models in Creative Industries. International Studies of Management \& Organization, 44(4), 43-62.

MacKinnon, D. W. (1965). Personality and the realisation of the creative potential. American Psychologist, 20(4), 273-281.

Marinova, E., Borza, A. (2014). The Creative Economy, the Creative Industries and New Perspectives for Creative Cities. Managerial Challenges of the Contemporary Society, 7(2), 22-26.

Martinaitytè E., Kregždaitè R. (2015). The Factors of Creative Industries Development in Nowadays Stage. Economics and Sociology, 8(1), 55-70.

Maryunani, S. R., Mirzanti, I. R. (2015). The Development of Entrepreneurship in Creative Industries with Reference to Bandung as a Creative City. Social and Behavioral Sciences, 169, 387-394.

Ministry of Culture, RL. (2018). LR KM informācija par kultūras un radošajām industrijām. Available at: https://www.km.gov.lv/lv/kultura/radosas-industrijas/ kulturas-un-radoso-industriju-definicija

Moyon, E., Lecocq, X. (2014). Rethinking Business Models in Creative Industries. International Studies of Management \& Organization, 44(4), 83-101.

Mumford, M. D., Gustafson, S. B. (1988). Creativity syndrome: Integration, application, and innovation. Psychological Bulletin, 103(1), 27-43.

Oldham, G., Cummings, A. (1996). Employee Creativity: Personal and Contextual Factors at Work. Academy of Management Journal, 39(3), 607-634.

Revelle, J. B. (2014). First creativity, then innovation. Industrial Engineer, 46(11), 31-35.

Schlee, R. P., Harich, K. R. (2014). Teaching Creativity to Business Students: How Well Are We Doing? Journal of Education for Business, 89(3), 133-141.

Shane, S., Nicolaou, N. (2015). Creative personality, opportunity recognition and the tendency to start businesses: A study of their genetic predispositions. Journal of Business Venturing, 30, 407-419.

Sik, A. (2016). Creativity in cross-domain collaborations: searching factors to increase efficiency. Management Research Review, 39(2), 144-166.

Sternberg, R. J. (1999). Handbook of Creativity. New York: Cambridge University Press, $490 \mathrm{p}$.

Sternberg, R. J. (2006). The Nature of Creativity. Creativity Research Journal, 18(1), 87-98.

Sung, T. K. (2015). Application of information technology in creative economy: Manufacturing vs. creative industries. Technological Forecasting \& Social Change, 96, 111-120. 
The Saeima of the Republic of Latvia. (10.06.2010.) Latvijas ilgtspejjīgas attīstības stratēgija līdz 2030. gadam, $100 \mathrm{p}$.

UNCTAD. (2008). The Challenge of Assesing the Creative Economy: towards informed policy-making, The Creative Economy Report. $332 \mathrm{p}$.

Zhou, J., Shalley, C. E. (2009). Handbook of Organizational Creativity. New York: Psychology Press, 393 p. 